\title{
Retailing, Private Label and Global Competition
}

\author{
Flavio Gnecchi ${ }^{*}$
}

\begin{abstract}
Global retailers define strategies coherent with local cultures and traditions, as also develop products centered on internationally diffused products. In this perspective, private labels become fundamental for such strategies as far as they contribute directly to store loyalty consolidation and indirectly, to retailers brand equity reinforcement. Moreover, private label products prove the retailer's sensibility in front of local customer's needs and preferences. As a consequence, global and local trade operators turn to local manufacturers, giving them a possibility to strengthen their corporate brand and the company itself by means of strategic alliances.
\end{abstract}

Keywords: Global Competition; Retailing; Private Label; Co-Packing

\section{Relationships Between Manufacturers, Retailing and Global Markets}

Relationships between the firms have surely transformed as a consequence of dynamic socio-economic changes occurring in the nowadays market. In particular, traditional boundaries of B2B have been actually widen in accordance with cooperative strategies logic (agreements, alliances, networks) in order to improve and adjust the offering to customer's needs and expectations (Brondoni 2003).

Omahe claims that "globalization mandates alliances, makes the absolutely essential to strategy. Uncomfortable, perhaps, but that's the way it is. Like it or not, the simultaneous developments that go under the name of globalization makeentente-necessary" (Ohmae, 1989) ${ }^{1}$.

Global markets reveal extremely rich in examples, offering an interesting and multidimensional perspective. On the other hand, however, multinational corporations (MNCs) have cleverly flanked global strategies with the local ones, mostly in reference to technologies, distribution and sales management. Retail channels are the best example of such philosophy. In fact, the companies operating in global retail trade can't overlook characteristics of local markets and consequently, their strategies choices have to be smartly pondered. Considering that

\footnotetext{
${ }^{*}$ Full Professor of Management, University of Milan-Bicocca (flavio.gnecchi@unimib.it)
} 
feasibility and costs may become an issue, global companies avail themselves of specific techniques like strategic alliances with local partners.

In reference to successful alliances we can identify five levels of integration (Hutt, Speh 2010):

- Strategic integration. Top management of both companies must be continuously in contact in order to pinpoint the objectives and discuss the changes;

- Tactical integration. Is developed among intermediate level managers in order to plan the activities, transfer the know-how, detect the changes related to the organization and the system's functioning;

- Operational integration. It supplies information and resources. It involves employees with specific skills necessary for current activities;

- Interpersonal integration. It strengthens the interpersonal relations between the employees, encourages the learning processes and gives value to the overall performance;

- Cultural integration. It promotes continuous relationships between top managers in order to identify guidelines that respect corporate culture of both parties.

Since a strategic alliance may be considered a perfect solution to satisfy local market's needs without quitting the global perspective, the companies operating in global retail trade are likely to leverage such technique in order to develop private label products. To achieve that, such companies turn to local, national companies consequently designated to produce and to launch new products with retailer's private label. Naturally, such technique shows an uncontested complexity directly related to the amount of markets where the company operates as also to a number of product categories in offer. Thus, global retailers need to analyse accurately all the local markets and, in particular, study their customers / consumers in order to identify different dimensions (cultural, socio-economic, psychographic, etc.) that drive their needs and behaviours in terms of consumption and purchase (Corniani 2005). This paper, then, is focused on identifying features and values that customers appoint to diverse products and, secondly, recognize models that drive demand's consumption and purchasing processes. Once acquired, such information determines and shape private label products but logically need to be pondered by feasibility evaluations. The feasibility evaluation, it is necessary to say, is related not only to a single product but also to the whole category which the retailer decides to handle.

\section{Private Label and Cooperative Strategies}

Global retailer's sales management policies hit the target with the private label products, which are manufactured not only by the biggest players on the market, but also by independent manufacturers, already present on the market with their own labels or if not, operating as a supplier of national / international companies. 
Such context gave a new life to the industry intermediate demand (semi-finished products, components, etc.) and as a consequence, it reinforced the whole supply chain.

Private Label Manufacturers Association (PLMA) - a non-profit organization founded in 1979 and representing more than 3,500 member companies around the globe- categorizes PL manufacturers into four main categories²:

1. National brand manufacturers that use their expertise and excess plant capacity to supply store brands.

2. Small, quality manufacturers who specialize in specific product lines and focus on producing store brands almost in an exclusive manner. Often these companies are owned by corporations that also manufacture national brands.

3. Retailers and wholesalers that own their own manufacturing facilities and provide store brand products for themselves.

4. Local brand manufacturers that manufacture private label products for specific markets.

Over-supply condition has significantly transformed the market structure and its dynamics, pushing the firms towards new solutions and continuous innovation in terms of offering and industry - trade relationship management (Brondoni, 2012). In particular, new technologies (i.e. ICT) and a greater role of distribution operators, gave birth to new selling forms like on-line auctions, expressly fostered by retailers in order to push private label products towards the demand. Such solutions may involve own IT systems or specialized virtual marketplaces like WWRE platforms (World Wide Retail Exchange), GNX and NEOGRID.

On-line auctions, however, have recently fostered numerous critiques from the manufacturer's side. In fact, the producers claim that such technique centers the competition on the price and no longer on quality or hypothetical value-added services that the industry could offer. According to the manufacturing operators, such policy could favor markets with low-wage workforce or, like in case of food industry - countries with longer fertility periods, and damage in the long term the whole private label section.

Increasing opportunities deriving from the private label section justify the validity of the organizations like PLMA, institutions and category unions, which are involved in promoting and protecting the interests of the whole industry, especially of the manufacturers.

Retailers, interested in developing their own private label product representing a specific category, are called to study the consumer first, trying to identify socioeconomic dimensions which drive his behavior. Such study is centered on information gathering about purchase and consumption experience of specific segments, attributions and values retained relevant by consumers. Secondly, once the information is complete, the retailer can decide visual aspects of private label products followed by the feasibility analysis in terms of development, timings and operations. Thirdly, the retailer decides the marketing plan of a single product taking into consideration aspects like selling and supply, as also - the contractual features of both. It becomes clear then, that choosing the right manufacturer (contract packer or co-packer) may be extremely complex and requires particular attention from the purchasing director. 


\section{Relationships Between Global Retailers and Co-Packers}

Once the supplier has been chosen, the trade identifies technical and qualitative aspects of the product, while the contract packer is called to verify that his operative structure is compatible with retailer's requirements and needs. Naturally, the transaction depends on bargaining power of the parties and the product itself is nothing but an expression of retailer's recommendations imposed on producers in reference to technical and commercial aspect.

Thus, it is possible to identify a number of economic and productivity factors that verify the reliability level:

- Economic dimensions

- Financial and economic analysis

- Organizational structure

- Production process efficiency level in order to guarantee supply's continuity and standards uniformity

- Typologies and levels of services offered by contract packer

Simultaneously, the retailer analyzes technical and manufacturing dimensions that characterize corporate structure of a potential co-packer:

- Degree of specialization and experience accumulated

- Level of research and development

- Efficiency of production structure

- Technologies in use

- Quality control management

It is necessary to underline also the importance of qualitative dimensions and not just the economic ones; in other terms, the price is no longer the main parameter, giving space to other, equally important elements like intrinsic quality, and services performed by co-packers.

Usually, the production control is accomplished at the early stage of product life cycle, that is, when the product is launched for the first time or in case of highly perishable products. In fact, the retailer is called to verify constantly the legitimacy of production processes and storage conditions in order to respect safety regulations and quality norms. If any problem occurs, the retailer and co-packer are both responsible for verifying and handling the issue. Secondly, the retailer may decide to keep or to remove the product from the market.

Not only the relationship between the client (retailer) and manufacturer (copacker) becomes critical, but also the whole supply chain needs to be seen in value chain perspective (Brondoni 2010). Thus, all the processes, activities and operations that involve global retailers and local manufacturers, must be integrated and coordinated, even more so in front of their role in local development. All the parties involved are called not only to handle the alliance, but also to keep it alive and efficient in time (Hutt, Speh 2010) ${ }^{3}$.

The private label phenomenon is booming and it has already become a centerpiece of modern retail marketing and $\mathrm{B} 2 \mathrm{~B}$ relations management. The 
success of private label products, in fact, is evident - also at the wholesale. Carrefour, for instance, operates in 34 countries (Europe, Asia, Latin America) with more than 10.000 markets and 160 cash \& carry warehouses, declared to aim at $40 \%$ of contribution of private labels on the whole income ${ }^{4}$.

Metro, one of the most important warehouses, possess a relevant number of private labels in both food and no-food products addressed mainly to professionals.

Thus, local producers can avail of different distribution channels like retailers willing to develop their own private labels distributed in supermarkets (final clients) or wholesales (professionals).

It is possible to identify three levels that may characterize relationships between manufacturers and trade operators:

- manufacturer's brand products - Manufacturers offer directly the products and they become at same time responsible for trade marketing management and for marketing and communication operations addressed to final clients;

- unbranded products - Typical products for some categories offered by retailers like fresh food (groceries like fruits, vegetables, meat and fish); the information regarding such products is focused on the origin (country or region) and not on a single manufacturer;

- private label products - Products commissioned directly by the retailer (of different dimensions) to co-packers.

This paper focuses more on the third level, discussing about the relationships between the co-packers and retailers, their roles and objectives.

Co-packers can boast different level of exposure. Some of them handle famous and appreciated brands, but decide to open to single retailers. On the other hand, some manufacturers are partially or even completely unknown to the public. All the producers however are protagonists of local, national or international economies.

Smaller manufacturers handling poorly known brands adhere more willingly to such kind of collaborations in virtue of major throughput and facility in finding not only new clients but also in finding new possible sales channels. The manufacturer's brand in this sense represents a starting point in processes of relationship consolidation with the committee, who in turn may favor the manufacturer's products in terms of shelf positioning. In fact the benefit is mutual: the retailer benefits from sales of private label products and co-packer, on the other hand, takes advantage from corporate's brand sales.

In contrast with private labels, some national or industrial brands manufacturers may be more attentive with retailer's business proposals as far as such solution may involve (in addition to all the benefits analyzed previously like achieving production saturation point, selling costs reduction and some managerial simplifications) a corporate strategy rethinking. In fact, even if such solution may procure some certainties in terms of future cash flows, a certain level of risk is always feasible, usually in reference to manufacturer's brand portfolio.

Considering the trade's purchasing power, a possible manufacturer's rejection must be justified by a congruent brand force (or brands force) on the market otherwise such refusal may reveal extremely harmful for the business. In fact, it is possible that in response to such refusal, the retailer could keep out manufacturer's 
leading brand (brand icon with a distinctive and recognizable trademark) from its shelves and force the clients to abandon the brand, even if leader of the category. It is difficult then to imagine a supermarket without the best known beverage or without the best known walnut butter, but it is due to an extremely strong position of these brands on the market and in their case, the retention risk becomes void.

The majority of brands, however, can be considered replaceable with other products representing the category. The producer may have to face one of following circumstances:

- be already a retailer's supplier; the relationship based on corporate brand and/or industrial brand handled by the manufacturer;

- the manufacturer is not a retailer's supplier yet and, as a consequence, needs to establish the relationship fundamentals (centered on the corporate brand);

It is possible, however, to identify two opposite behaviors in becoming a copacker:

- obstructionism: the manufacturer is not interested in developing this kind of collaboration, even if conscious about possible negative consequences on the relationship's stability;

- acceptance: the manufacturer decides to collaborate in virtue of mutual benefits in terms of profit and productivity, but also to avoid possible conflicts with retailers;

\section{Private Labels and Global Competition}

As previously observed, the importance of the brand impose on both parties retailer and manufacturer - a careful and pondered choice of the brand itself, but also extremely detailed and precise documentation regarding the process of supply. Law, on the other hand, does not constraint a retailer to give information about the manufacturers, but retains sufficient an information about the origin (country or region) of the item. Such choice, however, is often a fruit of inter-corporate evaluations and every decision of one of the parties (manufacturer or supplier) is scrupulously detailed in the contract.

Naturally also the retailer makes his evaluations, which, if correct, can translate into an outstanding performance. Private label's choice, then, depends on a number of internal and external factors like corporate culture, national/regional culture, external and internal environment, internationalization processes, globalization etc. (Tassinari 2005).

In reference to the brand management from the intermediary's point of view, centering proper policies on private label products leads directly to the evaluation of brand extension. Becoming a co-packer for a global operator means for a local manufacturer to manage its business more carefully in order to guarantee the best performance (also in terms of satisfaction generation) also in hypothesis of sales increase.

From the operational point of view, private labels became fundamental for the 
modern competition between the retailers, who now build their specificity on a set of own-labeled products and exclusive relationships with co-packers. In fact, the co-packer's reputation and notoriety may bolster the private label products competitiveness on the market. Exactly for that reason the choice of co-packer becomes crucial for 'power-plays' between retailers.

It is possible to notice that retailers who privilege store-brand policies are often partnered with manufacturers who already handle their own brand or brands; such contrast introduces a somewhat of 'managerial dualism' between mono-brand and multi-brand portfolio.

In case of generic products or low-cost products, on the other hand, there is no emphasis on the brand.

The fundamental objective, then, is to create exclusive brands, well-known and appreciated for their quality and convenience they generate in order to maximize customer's satisfaction and his store loyalty.

In some cases, however, the approach is nothing but a combination of already analyzed policies. In particular, in case of some notorious retailers, having created an exclusive private label product generated for all the parties a noteworthy benefits in terms of profit and notoriety. It is undeniable, then, a direct relationship between retailer's brand equity and his private label policies, which codify both: product and co-packer relationship management.

In a nowadays context where the brand loyalty, one of the brand equity drivers, faces a problem of 'customers switching', private label assumes an extremely relevant role - its exclusivity and a price/quality ratio influence directly the retailer's brand loyalty and indirectly, its brand equity.

It is evident that private label products phenomenon has significantly modified relation between manufacturers and trade; specially the second one has strengthen its position due to a number of factors like a direct contact with final consumers. It is true, however, that trade despite of its favored position retains important the nature of the relationship with manufacturers. In other words, retailers have recognized in co-packers an ally and a partner (local alliances), rather than a passive party, which numbly accomplishes retailer's commitments.

Retailers, global or local, have enriched their figure with a production role (even if executed by third parties), achieved as a result of specific agreements between the trade and co-packers.

\section{Bibliography}

Aaker David A. (2005) Strategic Market Management, John Wiley \& Sons Inc., Hoboken.

Arrigo Elisa (2012) Alliances, Open Innovation and Outside-in Management, Symphonya. Emerging Issues in Management (symphonya.unimib.it), n. 2, pp. 53-65.

http://dx.doi.org/10.4468/2012.2.05arrigo

Arrigo Elisa (2009) Market-Driven Management, Global Competition and Corporate Responsibility, Symphonya. Emerging Issues in Management (symphonya.unimib.it), n. 1, pp. 54-70. http://dx.doi.org/10.4468/2009.1.06arrigo

Batra Rajeev, Sinha Indrajit (2000) Consumer-Level Factors Moderating The Success Of Private Label Brands, Journal of Retailing, New York University, Vol. 76, pp. 175-191.

http://dx.doi.org/10.1016/S0022-4359(00)00027-0

Best Roger J. (2005) Market-Based Management, Pearson Prentice Hall, New Jersey. 
Braak Anne ter, Dekimpe Marnik G., Geyskens Inge (2013) Retailer Private-Label Margins: The Role of Supplier and Quality-Tier Differentiation, Journal of Marketing, Vol. 77, pp. 86-103.

Brondoni Silvio M. (2012) Innovation and Imitation: Corporate Strategies for Global Competition, Symphonya. Emerging Issues in Management (symphonya.unimib.it), n. 1, pp. 10-24. http://dx.doi.org/10.4468/2012.1.02brondoni

Brondoni Silvio M. (2010) Ouverture de Marketing Channel and Global Markets, Symphonya. Emerging Issues in Management (symphonya.unimib.it), n. 1, pp. 1-6. http://dx.doi.org/10.4468/2010.1.01ouverture

Brondoni Silvio M. (2005) Managerial Economics and Global Competition, Symphonya. Emerging Issues in Management (symphonya.unimib.it), n. 1, pp. 14-38. http://dx.doi.org/10.4468/2005.1.02brondoni

Brondoni Silvio M. (2003) Network Culture, Performance and Corporate Responsibility, Symphonya. Emerging Issues in Management (symphonya.unimib.it), n. 1, pp. 8-24. http://dx.doi.org/10.4468/2003.1.02brondoni

Brondoni Silvio M. (2002) Global Markets and Market Space Competition, Symphonya. Emerging Issues in Management (symphonya.unimib.it), n. 1, pp. 28-42. http://dx.doi.org/10.4468/2002.1.03brondoni

Chimhundu Ranga (2011) Private Label Marketing Performance: An Analysis of Historical trends Using Theories of cumulative Chianges and Puncutuated Equilibrium, Journal of Business and Management, Chapman University, n. 8, pp. 58-65.

Corniani Margherita (2012) Innovation, Imitation and Competitive Value Analysis, Symphonya. Emerging Issues in Management (symphonya.unimib.it), n. 2, pp. 37-52. http://dx.doi.org/10.4468/2012.2.04corniani

Corniani Margherita (2005) Market, Demand Segments and Demand Bubbles, Symphonya. Emerging Issues in Management (symphonya.unimib.it), n. 2, pp. 13-30. http://dx.doi.org/10.4468/2005.2.02corniani

de Woot Philippe (2002) The Challenges of Economic Globalisation: Business, Competition and Society, Symphonya. Emerging Issues in Management (symphonya.unimib.it), n. 2, pp. 11-21. http://dx.doi.org/10.4468/2002.2.03dewoot

Gnecchi Flavio (2009) Market-Driven Management, Market Space and Value Proposition, Symphonya. Emerging Issues in Management (symphonya.unimib.it), n. 2, pp. 33-45. http://dx.doi.org/10.4468/2009.2.04gnecchi

Gnecchi Flavio (2005) Brand Portfolio and Over Supply, Symphonya. Emerging Issues in Management (symphonya.unimib.it), n. 1, pp. 56-65. http://dx.doi.org/10.4468/2005.1.05gnecchi

Hitt Michael A., Ireland R. Duane, Hoskinsson Robert E. (2005) Strategic Management. Competitiveness and globalization, South-Western College Publishing, Thomson, Mason, $\mathrm{OH}$.

Hutt Michael D., Speh Thomas W. (2010) Business Marketing Management b2b, South Western Cengage Learning, Mason, $\mathrm{OH}$.

Lambin Jean-Jacques (2004), Market-Driven Management, MacMillan, London.

Lambin Jean-Jacques, Chumpitaz Rubén (2001), Market-Orientation and Corporate Performance, Symphonya. Emerging Issues in Management (symphonya.unimib.it), n. 2, pp. 23-37. http://dx.doi.org/10.4468/2001.2.03lambin.chumpitaz

Lincoln Keith, Thomassen Lars (2008) Private Label: Turning the Retail Brand Threat into Your Biggest Opportunity, MPG Books, Bodmin.

Ohmae Kenichi (1989) The Global Logic of Strategic Alliances, Harvard Business Review, MarchApril, pp. 143-154.

Rancati Elisa (2005) Global Markets and Time-Based Competition, Symphonya. Emerging Issues in Management (symphonya.unimib.it), n. 2, pp. 58-69.

http://dx.doi.org/10.4468/2005.2.05rancati

Riboldazzi Sabina (2010) Retail Policies in the Global Gasoline Market, Symphonya. Emerging Issues in Management (symphonya.unimib.it), n. 1, pp. 86-101. 
http://dx.doi.org/10.4468/2010.1.09riboldazzi

Salvioni Daniela M. (2010) Intangible Assets and Internal Controls in Global Companies, Symphonya. Emerging Issues in Management (symphonya.unimib.it), n. 2, pp. 39-51. http://dx.doi.org/10.4468/2010.2.04salvioni

Tassinari Vincenzo (2005), Trade, Over-Supply and Global Markets. The Coop Italia Case, Symphonya. Emerging Issues in Management (symphonya.unimib.it), n. 2, pp. 31-35. http://dx.doi.org/10.4468/2005.2.03tassinari

\section{Notes}

${ }^{1}$ Aaker observes that "Strategic alliances play an important role in global strategies because it is common for a firm to lack a key success factor for a market. It may be distribution, a brand name, a sales organization, technology, R\&D capability, or manufacturing capability. To remedy this deficiency internally might require excessive time and money. When the uncertainties of operating in other countries are considered, a strategic alliance is a natural alternative for reducing investment and the accompanying inflexibility and risk." David A. Aaker, Strategic Market Management, John Wiley \& Sons Inc., Hoboken, 2005, pp. 207-211.

2 www.plma.com

3 "A strategic global alliance (SGA) is a business relationship established by two or more companies to cooperate out of mutual need and to share risk in achieving a common objective. This strategy works well for market entry or to shore up existing weaknesses and increase competitive strengths. A U.S. firm with a reliable supply base might partner with a Japanese importer that has established distribution channels and customer base in Japan to form a strong entry into the Japanese market. Alliances offer a number of benefits, such as access to market or technology, economies of scale in manufacturing and marketing, and the sharing of risk among partners.

Although global strategic alliances offer potential, they pose a special management challenge. Among the stumbling block are these:

- Partners are organized quite differently for making marketing and product-design decisions, creating problems in coordination and trust.

- $\quad$ Partners that combine the best sell of skills in one country may be poorly equipped to support each other in other countries, leading to problems in implementing alliances on global scale.

- The quick pace of technological change often guarantees that the most attractive partner today may not be the most attractive partner tomorrow, leading to problems in maintaining alliances over time."

Michael D., Hutt, Thomas W. Speh, Business Marketing Management b2b, cit., p. 151

4 . www.carrefour.com "more than $75 \%$ of all Carrefour grocery products come from local suppliers. Carrefour intends to build on this approach and give its store managers - particularly in hypermarkets - more freedom so that they can select and offer their customers a very local selection of products sourced from producers located close to stores. Carrefour has always given priority to products sourced locally, i.e. products from the region in which they are sold. In Turkey and in Argentina, for example, $100 \%$ of all food products now come from national suppliers. In doing so, Carrefour is supporting the growth of thousands of SMEs and small producers, and is limiting $\mathrm{CO}_{2}$ emissions by not importing products. This emphasis in local products is based on the knowledge of local markets which store managers have acquired." 